\section{A New Eco-Friendly and Low Cost Additive in Water-Based Drilling Fluids}

Rudarsko-geološko-naftni zbornik

(The Mining-Geology-Petroleum Engineering Bulletin) UDC: 622.2

DOI: 10.17794/rgn.2021.5.1

Original scientific paper

\author{
Emine Yalman $^{1,2^{*}}$; Tolga Depci ${ }^{1}$; Gabriella Federer-Kovacs ${ }^{2}$; Hani Al Khalaf ${ }^{2}$ \\ ${ }^{1}$ Department of Petroleum and Natural Gas Engineering, Faculty of Engineering and Natural Sciences, Iskenderun Technical University, \\ 31200, Iskenderun-Hatay, Turkey. \\ ${ }^{2}$ Department of Petroleum Engineering, Faculty of Earth Science, University of Miskolc, 3515, Miskolc, Hungary.
}

\begin{abstract}
This study investigates the possibility of using rice husk ash as an additive to develop an environmentally friendly and low-cost drilling fluid system. Rice husk ash was added as an additive to water-based bentonite drilling fluids at different concentrations ranging from $2 \mathrm{wt} \%$ to $15 \mathrm{wt} \%$. The rheological and filtration properties of each developed drilling fluid were measured by using a viscometer and standard low-pressure low-temperature filter press. Subsequently, the cutting carrying index, the minimum annulus velocity required to clean the bottom of the well efficiently, the flow behaviour index and the permeability of mud cakes of the formulated systems were calculated in order to assess the performance of the systems. The results demonstrated that the rheological and properties were improved depending on the concentration of the rice husk ash introduced. With the introduction of $15 \mathrm{wt} \%$ concentration of rice husk ash, while apparent viscosity and yield point increased by $60 \%$ and $183 \%$, respectively, thixotropy and plastic viscosity decreased by $29 \%$ and $63 \%$, respectively. On the other hand, drilling fluid with $4 \%$ wt $\%$ content of rice husk ash reduced the fluid loss by $10 \%$. Moreover, the results showed that cutting the carrying index, the minimum annulus velocity required to clean the bottom of the well efficiently and the flow behaviour index of the enhanced with the exploitation of the rice husk ash in the drilling fluid. This study showed that rice husk ash is a promising additive to use in water-based bentonite drilling fluids when properly implemented, and hence reduces the impact on the environment, and the total cost for drilling.
\end{abstract}

\title{
Keywords:
}

drilling fluids; rice husk ash; environmental friendly; cutting carrying capacity; rheology; filtration.

\section{Introduction}

Drilling fluid is the main element of drilling engineering that has been used in the drilling industry worldwide and is essential since it performs several fundamental functions during drilling operations. The main functions of drilling mud are cleaning the hole, lifting the cutting to the surface, keeping the stability of the hole wall, and lubricating and cooling the bit (Caenn, 2011; Rabia, 2002; Bourgoyne, 1991).

There have been two main types of drilling fluid: water-based mud and oil-based mud. Selecting the correct type requires experience and an understanding of drilling engineering to prevent any drilling problems. Generally, water-based mud is the common type in the drilling industry due to one main reason, which is that the cost of water-based mud is lower than that of oil-based mud (Amanullah, 2007). Chemical additives in water-based drilling fluid can be in a solid or liquid state. The chemical additives are important components of drilling fluid because they control many important properties, such as

Corresponding author: Emine Yalman

emine.avci@iste.edu.tr rheology, fluid loss, cake thickness and density. There are many types of these additives that give positive results to improve rheology and density and reduce fluid losses and cake thickness, like bentonite, barite, polymers, and many others (Amanullah, 2007). The selection of these additives depends on the task required. For example, some additives increase the viscosity of the drilling fluid, while others reduce it. The main problem with these additives is that they are expensive, which negatively affects the total cost of drilling, as well as health, safety, and environmental impacts. Some drilling fluids can be highly toxic and can poison employees if used incorrectly. Therefore, a decision has been made to seek new, safe, and low-cost alternatives to those chemical additives. Degradable materials are the main option because they do not cause any environmental damage, they are cheap and available in large quantities, as opposed to non-degradable chemical additives. Rice husk ash is an important agricultural waste material.

In many countries, rice husk is considered agricultural waste, obtained by removing it from white rice during the sieving process, and there is no real use for it. It is available in large quantities since 700 million tons of 


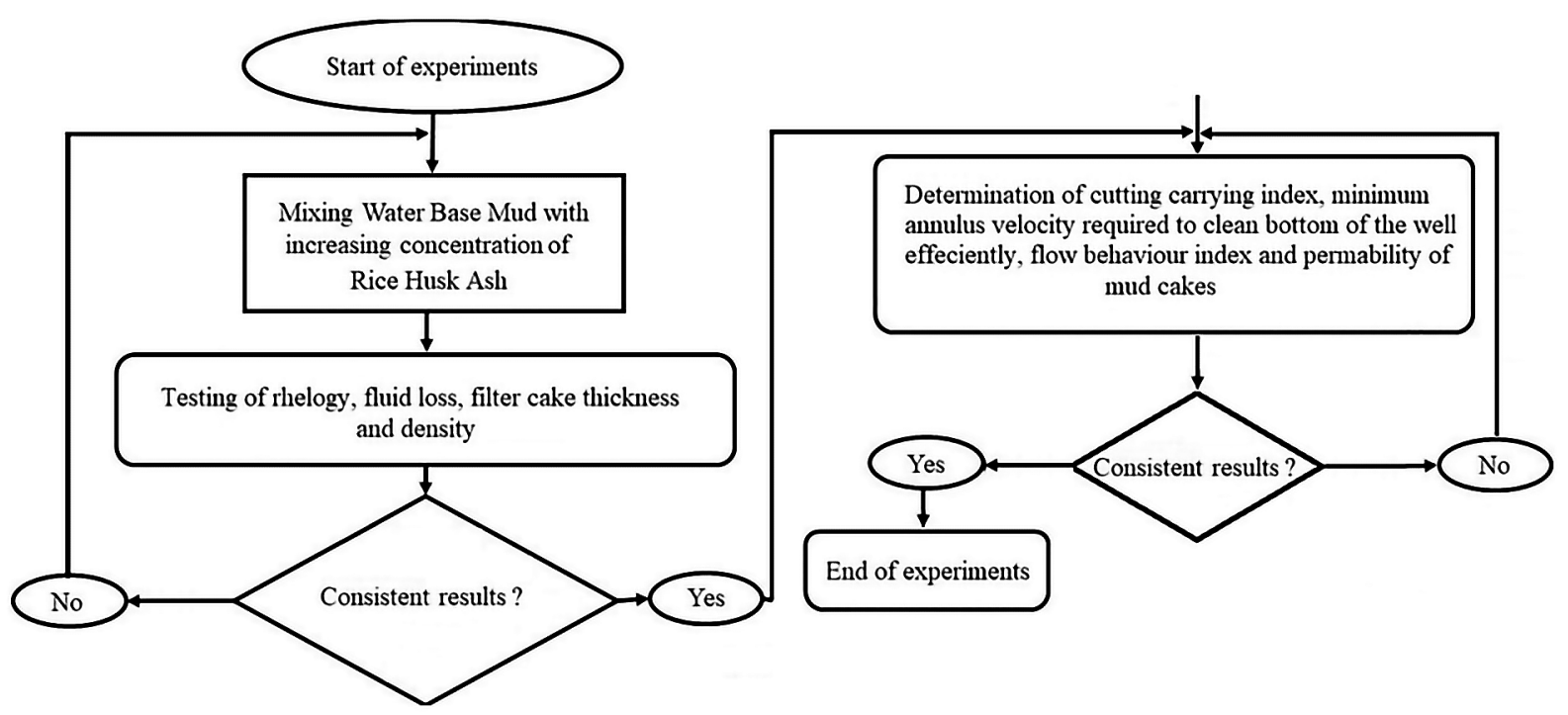

Figure 1: Flowchart of the experimental study

rice have been produced around the world annually. The proportion of rice husk is about $20 \%$ of the rice production and 20\% of this husk amount is ash (Malhotra, 1993). Rice husk has been used as fuel to boil rice in rice factories in some countries or it is burned in the fields, which contributes to air pollution (Sensale, 2006). There have been some applications of rice husk ash in civil engineering as a partial replacement for concrete (Adnan et al., 2021; Akeke et al., 2013). In addition, rice husk ash has been used in soil conditioner, brick, silica powders, insulator, biochar, activated carbon, epoxy coating, and heat absorbing glass (Prasara and Gheewala, 2017).

A quick glance at the literature will suffice to understand how much attention has recently been drawn by researchers regarding studies on environmentally friendly materials as an alternative to traditional chemical additives. Potato peel powder (Al-Hameedi et al., 2019a), rice husk (Okon, 2014), pomegranate peel powder and sugar cane (Al-saba, 2018), palm tree leave powder (AlHameedi et al., 2019c), fibrous food waste (Al-Hameedi et al., 2019b), pomelo peel powder (Zhang et al., 2020), banana peel powder (Al-Hameedi et al., 2020), grass powder (Al-Hameedi et al., 2019d) and moringa oleifera leaves (Biwott et al., 2019) are among the many materials studied in water-based drilling fluid. However, neither the use of rice husk ash in bentonite mud with additives nor the hydraulic performances of these degradable materials based on the cutting carrying index, the minimum annulus velocity required to clean the bottom of the well efficiently, the flow behaviour index and the permeability of mud cakes have been analysed by investigators.

This paper presents an experimental study on rice husk ash as an additive to water-based bentonite drilling fluid with additive and a determination of its effect on many properties of drilling fluid, such as rheology, den- sity, fluid loss and cake thickness. In addition, the cutting carrying index, the minimum annulus velocity required to clean the bottom of the well efficiently, the flow behaviour index and the permeability of mud cakes of the formulated systems were analysed in order to assess the performance of the systems. Evaluating rice husk ash as an environmentally friendly and cost-effective drilling fluid additive greatly reduces the negative impact on the environment, provides personal safety, and decreases the total cost for drilling.

\section{Experimental}

All experimental measurements for this article were carried out based on standards of the American Petroleum Institute (API) recommended practice API-RP13B-1. Workflow for the experimental process is shown in Figure 1. Rheological and filtration properties of water-based bentonite drilling fluid, which are plastic viscosity, apparent viscosity, yield point, gel strength for 10 seconds, $1 \mathrm{~min}$, and 10 minutes, density, and the fluid loss for 30 minutes, as well as the thickness of the cake were recorded for drilling fluid systems with different concentrations of rice husk ash. In addition, elemental analysis and particle size distribution of the rice husk ash used were identified by using Rigaku Supermini 200 type X-ray fluorescence (XRF) spectrometer and HORIBA LA-950V2 laser diffraction particle size analyser, respectively. Also, specific surface area (SSA) of the rice husk ash was computed with the laser sizer software using particle size distribution data.

\subsection{Materials}

In this study, rice husk ash is the main material used as an additive to water-based bentonite drilling fluid. Rice husk is an important by-product of rice milling and 


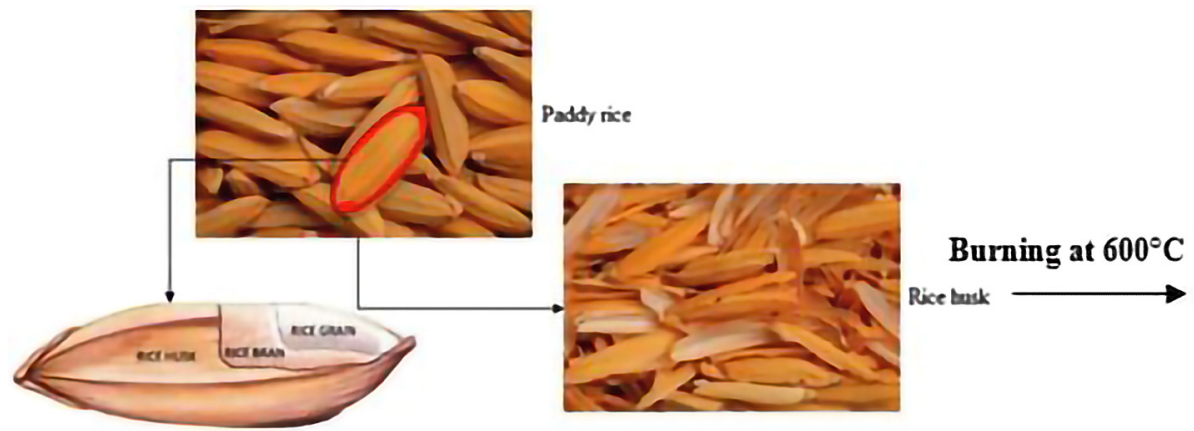

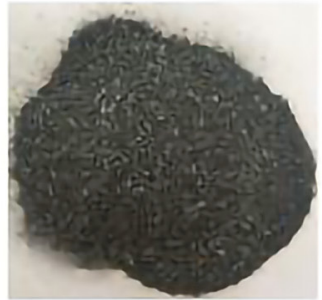

Rice husk ash

Figure 2: Production of rice husk ash (Derived from Fernandes et al., 2016; Buggenhout et al., 2013; Kieling, 2009).

Table 1. Chemical composition of rice husk ash

\begin{tabular}{|c|c|}
\hline Oxides & $\mathbf{( w t \% )}$ \\
\hline $\mathrm{SiO}_{2}$ & 97.3 \\
\hline $\mathrm{Al}_{2} \mathrm{O}_{3}$ & 0.2 \\
\hline $\mathrm{MgO}$ & 0.51 \\
\hline $\mathrm{CaO}$ & 0.65 \\
\hline $\mathrm{Na}_{2} \mathrm{O}$ & 0.13 \\
\hline $\mathrm{K}_{2} \mathrm{O}$ & 2.68 \\
\hline $\mathrm{Fe}_{2} \mathrm{O}_{3}$ & 0.14 \\
\hline $\mathrm{MnO}$ & 0.195 \\
\hline $\mathrm{TiO}_{2}$ & 0.011 \\
\hline $\mathrm{P}_{2} \mathrm{O}_{5}$ & 0.429 \\
\hline
\end{tabular}

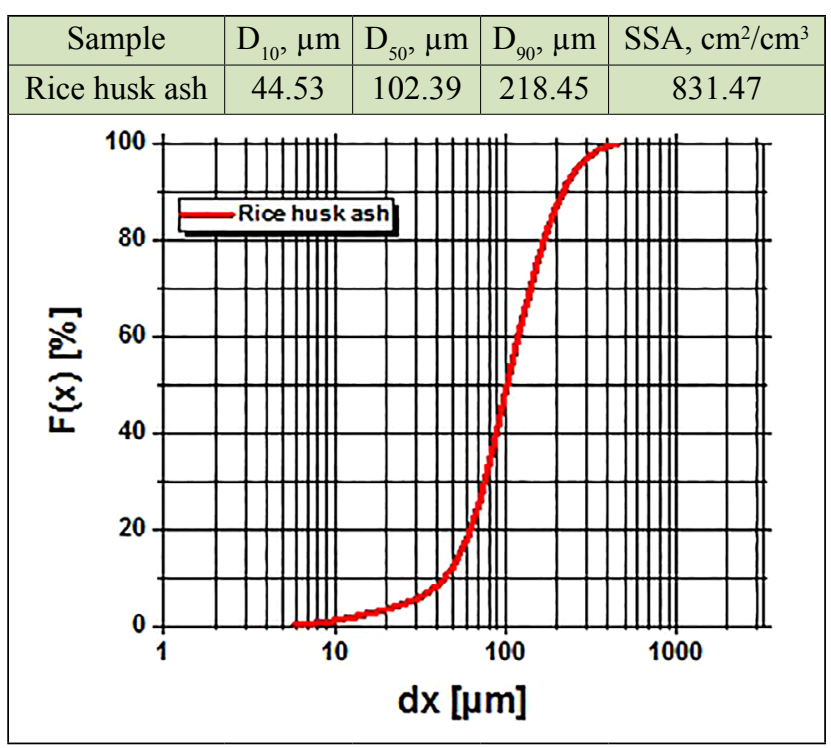

Figure 3: Particle size distribution of rice husk ash

is produced in large amounts worldwide each year. Rice husk ash is a good pozzolan material and its colour and chemical composition vary depending on where the raw material comes from, the burning method, time, duration and temperature (Thomas, 2018). The rice husk ash used in the study was obtained from a food company located in Edirne/Turkey and produced by burning rice husk at 600 degrees. Its colour is dark gray and its spe- cific weight is $0.18 \mathrm{~g} / \mathrm{cm}^{3}$. Production of the rice husk ash can be seen in Figure 2. In addition, elemental analysis and particle size distribution results of the rice husk ash are given in Table $\mathbf{1}$ and Figure 3, respectively. As can be seen from the table, the rice husk ash mainly consists of silicon oxide $\left(\mathrm{SiO}_{2}\right), 97.3 \%$, and potassium oxide $\left(\mathrm{K}_{2} \mathrm{O}\right), 2.68 \%$, with negligible amounts of aluminium oxide $\left(\mathrm{Al}_{2} \mathrm{O}_{3}\right), 0.2 \%$, magnesium oxide $(\mathrm{MgO}), 0.51 \%$, calcium oxide $(\mathrm{CaO}), 0.65 \%$, sodium oxide $\left(\mathrm{Na}_{2} \mathrm{O}\right)$, $0.13 \%$, iron (III) oxide $\left(\mathrm{Fe}_{2} \mathrm{O}_{3}\right), 0.14 \%$, manganese (II) oxide $(\mathrm{MnO}), 0.195 \%$, titanium dioxide $\left(\mathrm{TiO}_{2}\right), 0.011 \%$ and phosphorus pentoxide $\left(\mathrm{P}_{2} \mathrm{O}_{5}\right), 0.429 \%$. In Figure 3, while the $\mathrm{x}$-axis denotes the particle diameter of rice husk ash, the y-axis shows cumulative undersize particles $(\%)$. The median particle size $\left(\mathrm{D}_{50}\right)$ of the rice husk ash is $102.39 \mu \mathrm{m}$ and its specific surface area is 831.47 $\mathrm{cm}^{2} / \mathrm{cm}^{3}$, as can be seen in Figure 3 .

\subsection{Preparation of drilling fluids}

The study was based on water-based bentonite mud, which is frequently used in well drilling. In addition to bentonite, xanthan gum (XG) was used as a viscosity modifier agent, while carboxymethyl cellulose (CMC) was used as a water loss control additive. $\mathrm{XG}$ is a biopolymer with a molecular weight $>1000000$, formed by fermenting glucose, sugar or hydrated starch by an aerobic bacteria called Xanthomonas campestris and the $\mathrm{CMC}$ is a low molecular weight, low viscosity polymer designed specifically for use in water-based drilling fluids, effectively reducing the filtration rate of water-based drilling fluids without causing significant increases in viscosity or gel strength. To recognize the impact of adding rice husk ash with different concentrations on the properties of the drilling mud, one system of freshwater bentonite mud consisting of bentonite, freshwater, $\mathrm{XG}$, CMC was prepared as a control fluid, and the composition of the mud is shown in Table 2. After that, rice husk ash with planned concentrations were introduced to the mud by using a drilling fluid mixer. For the preparation process, initially, the freshwater planned to formulate the mud samples was poured into the mixer cup. Then the planned weight of bentonite was added and mixed continuously until homogeneity for 20 minutes. After 
Table 2. Formulation of water based drilling mud

\begin{tabular}{|c|c|}
\hline Additives & Compositions \\
\hline Bentonite $[\mathrm{g}]$ & $22.5[6.4 \%]$ \\
\hline Water $[\mathrm{mL}]$ & 350 \\
\hline $\mathrm{XG}[\mathrm{g}]$ & 0.5 \\
\hline CMC $[\mathrm{g}]$ & 1 \\
\hline
\end{tabular}

that, with continuous mixing, the planned weight of $\mathrm{XG}$ and $\mathrm{CMC}$ was added slowly and sequentially to prevent agglomeration and mixed continuously until homogeneity for 5 minutes. After this stage was over, the drilling fluid was left for 24 hours before being used in the tests. The results of these tests were analysed based on the different concentrations of rice husk ash to understand the effect of using different concentrations of rice husk ash on the performance of fresh water-based bentonite mud and to determine the optimum concentration of rice husk ash.

\subsection{Rheological determination}

A Fann model 35A rotational viscometer was used to measure the rheology properties. The mud sample was poured into the viscometer cup to the mark level and placed on the viscometer device after setting the rotor in his place. The rotor speed was applied at 3,6, 100, 200, 300 , and 600 revolutions per minute $[\mathrm{r} / \mathrm{min}]$ and their dial readings were recorded and used to calculate the apparent and plastic viscosity as well as its yield point. For the calculation of plastic viscosity (PV), apparent viscosity (AV), and yield points (YP) of each sample of mud, some equations are required. The following equations were used in the calculation of the parameters in accordance with API recommended practice of standard procedures (Recommended Practice, 1988).

Apparent viscosity (AV) in [mPa-s]:

$$
\mathrm{AV}=\Theta_{600} / 2
$$

Plastic viscosity (PV) in [mPa-s]:

$$
P V=\Theta_{600}-\Theta_{300}
$$

Yield point $(\mathrm{YP})$ in $[\mathrm{Pa}]$ :

$$
\mathrm{YP}=0.511 *\left(\Theta_{300}-\mathrm{PV}\right)
$$

Where:

$\Theta_{600}$ : dial reading at $600[\mathrm{r} / \mathrm{min}]$,

$\Theta_{300}$ : dial reading at $300[\mathrm{r} / \mathrm{min}]$.

Gel strength was determined as one of the mud rheological properties for 10-second (Gel10s), 1-minute (Gel1 min) and 10-minute (Gel10min) gel strength of the mud. Therefore, the viscometer was run for 10 seconds at $600[\mathrm{rpm}]$, then, the viscometer was switched off for 10 seconds. As the next step, the rotary speed was switched to a low value 3 [rpm] and the maximum dial reading was recorded as the gel strength value. The procedure was repeated for 1-minute and 10-minute gel strength with the switch of the period in the duration of 1 and 10 minutes respectively.

\subsubsection{Determination of cutting carrying index (CCI)}

The amount of cutting in the annulus is based on the drilling rate and the carrying capacity of the drilling fluid. One of the primary functions of the drilling fluid is to carry the cutting pieces through the annular space to the surface. Otherwise, cuttings gather around the drill pipes, the drill pipes will be stuck, and the drilling operations cannot be continued. For that, it is important to get a clear idea about the hole cleaning by using Cutting Carrying Index (CCI) method. The CCI is an experimental relationship and can be calculated from Equation (4). The average annulus mud velocity $(\mathrm{V} \alpha)$ accepted for an effective well cleaning in vertical and near-vertical angled wells in the drilling industry is specified as $100 \mathrm{ft} /$ min (Bourgoyne, 1991). Therefore, CCI of the mud samples formulated was calculated by assuming the annulus velocity to be $100 \mathrm{ft} / \mathrm{min}$. Minimum annulus velocity of the samples was also calculated with assumption magnitude of cutting carrying index as 1.0.

$$
C C I=\frac{V_{\alpha} \rho_{m} K}{400000}
$$

Where:

$\mathrm{V} \alpha$ : annular velocity, (ft/min),

$\rho_{\mathrm{m}}$ : mud density, (lb/gal).

$\mathrm{K}$ : Power Law flow consistency index, (mPa-s), which can be calculated from the following equation:

$$
K=\frac{510 \theta_{300}}{511^{n}}
$$

$\mathrm{n}$ : flow behaviour index, which can be computed from the following equation:

$$
n=3.32 \log \frac{\theta_{600}}{\theta_{300}}
$$

Based on Equation (4), if the value of $\mathrm{CCI} \leq 0.5$, this means the hole clean efficiency is low.

And if the value of $\mathrm{CCI} \geq 1.0$, this means the hole clean efficiency is high.

\subsection{Determination of fluid loss}

By using an API LT-LP (American petroleum institute low temperature-low pressure) filtration device at room temperature and 0.68 MPa pressure, the fluid loss for 30 minutes was determined. The cylindrical cell of LT-LP filter press was filled by the mud after the filter paper was placed at the inner bottom of the cylindrical cell. Thereafter, the cylindrical cell was closed tightly and placed on the cell holder. $0.68 \mathrm{MPa}$ pressure from a nitrogen bottle was supplied to the top of the cylindrical cell. Under the 
effect of nitrogen pressure, the filtrate fluid starts to come out through the filter paper and this filtrate fluid was collected by a graduated cylinder placed below the cell for 30 minutes and recorded in [ml]. Finally, the cake thickness of the mud on the filter paper was measured using a graduated ruler and recorded in [mm].

\subsubsection{Mud cake permeability}

Based on the experiments of this study, the thickness of the cakes was compared. After the fluid loss experiment was finished, the cell of API LT-LP filtration device was removed, the filter paper was taken out and the cake thickness was measured. The thickness was measured from five different locations on the filter paper to get the correct thickness of the mud cake. Darcy's law is commonly used to express the flow of fluids through pores. A high thickness of the mud cake that means that there is high fluid loss inside the formation. Thus, the permeability of the mud cake should be reduced to decrease the volume of the fluid loss. The permeability of the mud cakes is calculated from the following equation (Azar and Samuel, 2007; Dandekar, 2013; Kok and Bal, 2019):

$$
k=\frac{Q \mu L}{A \Delta P}
$$

Where:

$\mathrm{k}$ : cake permeability,

Q: the flow rate $\left[\mathrm{cm}^{3} / \mathrm{s}\right]$,

$\mu$ : the viscosity of liquid phase of the mud inside the chamber [mPa-s],

L: the thickness of the mud cake $[\mathrm{cm}]$,

A: the area of the filter disk or filter paper $\left[\mathrm{cm}^{2}\right]$,

$\Delta \mathrm{P}$ : the pressure drop across the filter cake [atm].

Depending on the previous equation and considering the area of the filter paper, the viscosity of the liquid phase of mud and the pressure drop remain constant, therefore the equation becomes as follows:

$$
\frac{k 1}{k 2}=\frac{Q 1 L 1}{Q 2 L 2}
$$

That means the permeability ratio of two mud cakes can be determined by the ratio of multiplying the value of water loss by the thickness of the first mud cake to multiplying the value of water loss by the thickness of the second mud cake.

\subsection{Determination of density}

The mud balance was used to measure the mud density. The balance cup was completely filled by the mud sample to be determined after ensuring the cup was clean and dry. The cover was installed on the cup as some mud slipped out of the vent on the cover to ensure that there was no air captured in the cup. The cup and cover were cleaned on the outside to remove any mud on the surface in order to get a correct measurement. The moving weight was moved until the cup and the moving bubble of the device rested in the middle, between the two black lines. Thereafter, the density of the mud sample was recorded as the weight was in equilibrium by placing the arm ruler of the mud balance by $[\mathrm{lb} / \mathrm{gal}]$ unit.

\section{Results and Discussion}

The rheological and filtration properties of waterbased bentonite drilling mud in the absence and in the presence of different concentrations $(2,4,7,9,12.5,15$ $\mathrm{wt} \%$ ) of rice husk ash were investigated and the results are presented below.

\subsection{Analysis of rheology}

In this section, the apparent viscosity, the plastic viscosity, the yield point, the gel strength (Gel10s, Gel1min, Gel10 min), the minimum annular velocity required for effective hole cleaning, the cutting carrying capacity, and the flow behaviour index were measured and calculated based on data obtained with a Model 35A viscometer.

Apparent viscosity is one of the main characteristics of drilling fluid and plays a fundamental role in the assessment of drilling fluid. The apparent viscosity of drilling fluid must be high enough to suspend drilled cutting and perform well cleaning effectively. Inadequate apparent viscosity of a drilling fluid may cause serious problems that can lead to the abandonment of a well. Figure 4 demonstrates the apparent viscosity results of water-based bentonite drilling fluid systems formulated with the absence and presence of different amounts of rice husk ash. Referring to Figure 4, the use of rice husk ash in the drilling fluid has an improvement in the apparent viscosity of the mud. The apparent viscosity of all samples incorporated with rice husk ash experienced higher apparent viscosity compared to the base drilling fluid without rice husk ash. The apparent viscosity of the

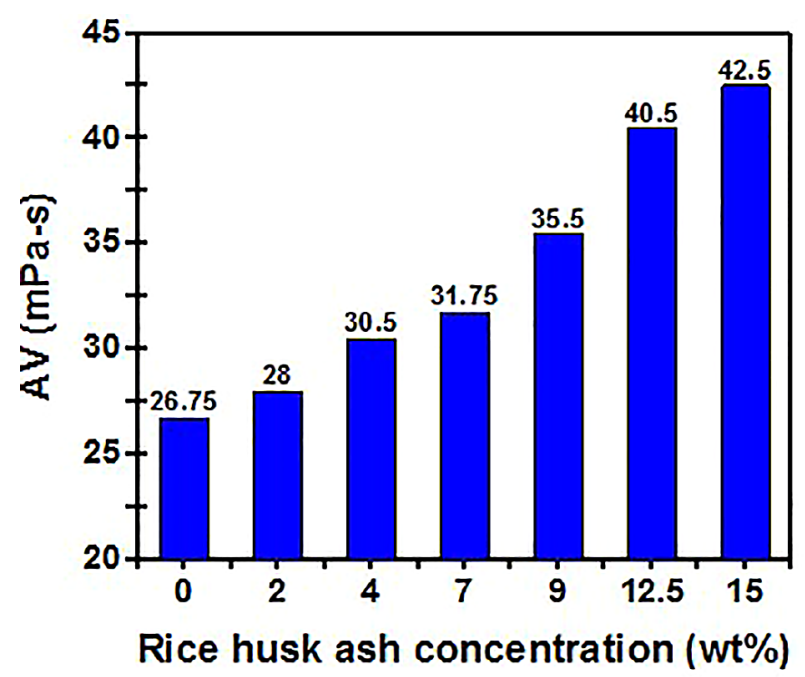

Figure 4: Apparent viscosity of water-based bentonite mud with the addition of different rice husk ash concentrations 
fluid increased by $60 \%$ with the formulation of $15 \mathrm{wt} \%$ concentration of rice husk ash. It should be emphasized that (Al-Hameedi et al., 2019a), (Al-saba, 2018), (AlHameedi et al., 2019b) and (Al-Hameedi et al., 2019c) have not examined a variation of apparent viscosity with the use of environmental materials in their studies.

Figure 5 shows a variation of the plastic viscosity of mud with the addition of rice husk ash. The plastic viscosity resulting from mechanical friction between particles in the mixture is proportional to the solid content in the drilling fluid. Increasing the solid content causes an increase in plastic viscosity. In addition, the decrease in the particle size of the solid material causes the plastic viscosity to increase further. On the other hand, the plastic viscosity is desired to be as low as possible in drilling operations to decrease frictional pressure loss during the circulation of a drilling fluid (surface system, drill string, drill bit and annulus). The increased pressure losses cause a higher equivalent circulating density (ECD) and pump pressure. The higher ECD may be unacceptable and cause fractures in the formations, particularly where the margin between pore pressure and fracture pressure is narrow, thus leading to a considerable increase in drilling cost. Figure 5 indicates that plastic viscosity of the water based bentonite mud improved with the employment of rice husk ash. Increasing concentration of the rice husk ash up to $7 \mathrm{wt} \%$ constantly decreased the plastic viscosity. However, a reduction was observed when the concentration was increased to $9 \mathrm{wt} \%$. Beyond this point, the plastic viscosity decreased again due to the increase in the concentration of rice husk ash and the lowest plastic viscosity was observed with the employment of $15 \mathrm{wt} \%$ rice husk ash, when the plastic viscosity decreased by $53 \%$. However, it should be noted that all water-based bentonite drilling fluid systems incorporated with rice husk ash had lower plastic viscosity, except for the $9 \mathrm{wt} \%$ sample, compared to the mud system without rice husk ash. It should be emphasized that these results are better than previous studies. For instance, (Al-saba, 2018) and (Al-Hameedi et al., 2019b) used sugar cane and fibrous food waste material in waterbased drilling fluid, respectively. Their common results showed that the plastic viscosity increased with the addition of the materials, despite the improvement in other rheology and filtration properties compared to the reference fluid.

The yield point is the degree of attraction between particles in the drilling fluid system and shows the carrying capacity of a drilling fluid. A higher yield point will provide higher carrying capacity, thus better hole cleaning and a decrease in the associated problems with inadequate hole cleaning. Figure 6 represents the results of the yield point of the mud with the addition of different concentrations of rice husk ash into the water-based bentonite drilling fluid. Similar to plastic viscosity, while up to $7 \mathrm{wt} \%$ concentration of rice husk ash, the yield point of the mud increased, a reduction was observed for 9

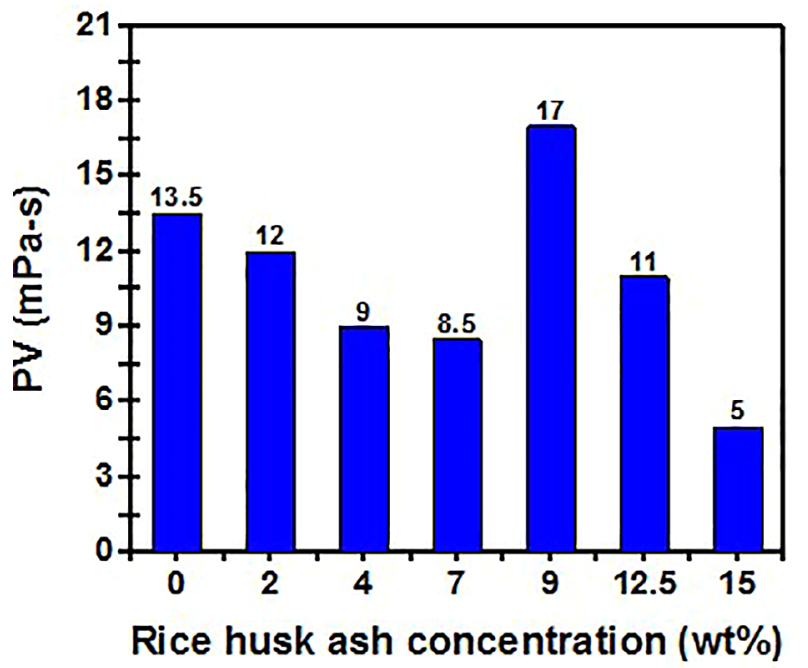

Figure 5: Plastic viscosity of water-based bentonite mud with the addition of different rice husk ash concentrations

$\mathrm{wt} \%$ concentration. Beyond this point, the yield point increased constantly with the increasing concentration of rice husk ash and the highest yield point was obtained with a drilling fluid system that incorporated $15 \mathrm{wt} \%$ rice husk ash, which increased the yield point by $183 \%$. In the study of (Al-saba, 2018), it was observed that when pomegranate peel powder is used in water-based mud, it reduces its yield point.

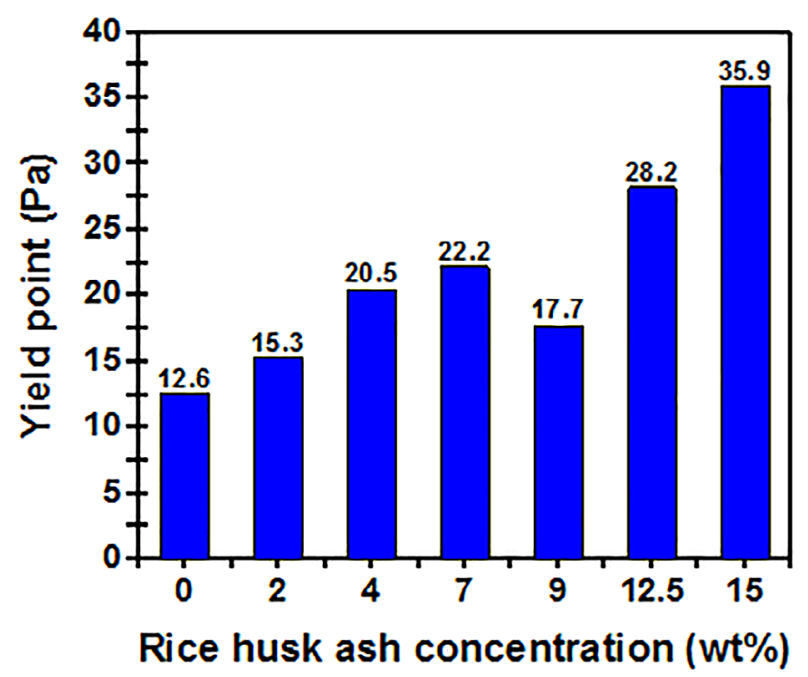

Figure 6: Yield point of water-based bentonite mud with the addition of different rice husk ash concentrations

Gel strength is another significant parameter of drilling fluid and refers to the thixotropic behaviour of drilling fluid. Thereby, it measures the ability of a fluid to develop gel strength with time in order to suspend cuttings in a static condition and flow when sufficient force is applied (Rabia, 1985; Culver, 1998). Therefore, the thixotropy of the measured fluids were estimated by the difference in the 10-minute and 10-second gel strength. 
Table 3 shows that 1-minute gel strength (Gel1 min) and 10-minute gel strength (Gel10min) increased constantly with the increasing concentration of rice husk ash. However, the 10 -second gel strength (Gel10s) increased up to a $7 \mathrm{wt} \%$ concentration of rice husk ash while it decreased with the $9 \mathrm{wt} \%$ concentration. Beyond the $9 \mathrm{wt} \%$ concentration, Gel10s increased with the increasing concentration. Another observation is the lowest thixotropy was obtained with a $15 \mathrm{wt} \%$ concentration of rice husk ash, whereas the highest thixotropy was seen with $7 \mathrm{wt} \%$ concentration of rice husk ash. The thixotropy decreased by $29 \%$ when a $15 \mathrm{wt} \%$ concentration of rice husk ash was introduced into the water-based bentonite drilling fluid. When the results were compared with the literature, it was observed that (Al-Hameedi et al., 2019a) achieved a thixotropy reduction of about $20 \%$ by using potato skins in water-based mud. On the other hand, (Alsaba, 2018) when 2 ppb of pomegranate peel powder and $5 \mathrm{ppb}$ of banana peel were used independently in the water-based spud mud, it was observed that the gel strength decreases with the exploitation of the materials.

When the rheological results obtained in the study were evaluated as a whole, superior results were observed when compared to other studies. For instance, (Al-Hameedi et al., 2019c) in a study using palm tree leave powder, corncob and sugar cane (Irawan et. Al., 2009) and potato peel (Al-Hameedi et al., 2019a) in a water-based drilling mud, although the filtration properties improved, it was observed that the rheological properties were negatively affected as the plastic viscosity increased and the yield point and gel strength decreased with the use of the materials compared to the reference fluid.

Table 3. Gel strength (Gelıos, Gelımin, Gelıomin) of water-based bentonite mud with the addition of different rice husk ash concentrations

\begin{tabular}{|l|l|l|l|}
\hline $\begin{array}{l}\text { Concentration of rice } \\
\text { husk ash (wt\%) }\end{array}$ & $\begin{array}{l}\text { Gel10s, } \\
(\mathbf{P a})\end{array}$ & $\begin{array}{l}\text { Gel1 min., } \\
\mathbf{( P a )}\end{array}$ & $\begin{array}{l}\text { Gel10min., } \\
\text { (Pa) }\end{array}$ \\
\hline 0 & 8.61 & 14.84 & 23.46 \\
\hline 2 & 9.09 & 16.27 & 25.37 \\
\hline 4 & 10.05 & 17.23 & 26.81 \\
\hline 7 & 13.40 & 18.19 & 28.72 \\
\hline 9 & 11.49 & 18.19 & 28.72 \\
\hline 12.5 & 11.97 & 18.67 & 31.60 \\
\hline 15 & 13.88 & 20.58 & 33.03 \\
\hline
\end{tabular}

Table 4 shows the results of the cutting carrying index and the minimum annulus velocity required for effective hole cleaning of water-based bentonite drilling fluid in the absence and the presence of the different concentrations of rice husk ash, calculated by using Equation (4). Table 4 also shows the results of variation of flow behaviour index of the water based bentonite drilling fluid when incorporated with different concentrations of rice husk ash calculated by using Equation (6).
One of the most important parameters in the evaluation of the quality of a drilling fluid is its cutting carrying capacity. The cutting carrying index defines the ability of a drilling fluid to transport drilled cuttings up to the surface. Improper carrying capacity of a drilling fluid may cause a decrease in the rate of penetration, a stuck pipe due to the accumulation of cutting in the bottom of the well, high torque and drag, insufficient hole cleaning and associated serious problems (Bourgoyne et al., 1991, Caenn et al., 2011). On the other hand, the achievement of lower minimum annulus velocity is a favourable characteristic of a drilling fluid due to the declining cost of drilling operations (Caenn et al., 2011). In addition, the flow behaviour index indicates the degree of shear thinning capability of a drilling fluid and as the value of the flow behaviour index decreases as the fluid becomes more shear thinning. The shear thinning behaviour is a desired characteristic of a drilling fluid. It means that the viscosity of a drilling fluid decreases with an increase in shear rate. For instance, a drilling fluid becomes thinner in drill string and drill nozzle flows where high shear rates are experienced by transmitting more hydraulic power to the drill bit, thereby reducing pressure losses. On the other hand, it helps to clean the well by increasing the carrying capacity of drilling fluid, which behaves more viscous in the annulus where low shear rates develop (Rabia, 2002; Skalle, 2011).

From Table 4, it is clear that the cutting carrying index of the drilling fluid improved with the addition of rice husk ash. While the cutting carrying capacity increased steadily up to a $7 \mathrm{wt} \%$ concentration of rice husk ash, a reduction was observed when the concentration was increased to $9 \mathrm{wt} \%$. However, concentrations higher than $9 \mathrm{wt} \%$ resulted in a further increase in the cutting carrying index of the fluid. It is worth noting that at high concentrations of rice husk ash, which are 12.5 and 15 $\mathrm{wt} \%$, the increase in the cutting carrying index is significantly higher than in the lower concentrations, which are $2,4,7,9(\mathrm{wt} \%)$. The addition of a $15 \mathrm{wt} \%$ concentration of rice husk ash to the drilling mud allowed for an increase in the cutting carrying index from 3.183 to 54.700 . On the other hand, it is obvious that the use of rice husk ash in the water-based bentonite drilling fluid decreased the minimum annulus velocity, as can be seen in Table 4 and a lower minimum annulus velocity was obtained in all the samples blended with rice husk ash, regardless of its concentration, in comparison with the base fluid. As is well known, since a higher cutting carrying index provides lower minimum annular velocity, results opposite to the cutting carrying index pattern were obtained, as expected. While minimum annular velocity decreased constantly up to a $7 \mathrm{wt} \%$ concentration of rice husk ash, while a $9 \mathrm{wt} \%$ concentration of rice husk ash caused an increase in the velocity. Nevertheless, with the use of a concentration higher than $9 \mathrm{wt} \%$, the minimum annular velocity decreased further, and the lowest annular velocity was obtained with the sample formulated with a 15 
$\mathrm{wt} \%$ concentration of rice husk ash. The addition of the $15 \mathrm{wt} \%$ concentration of rice husk ash to the drilling mud allowed for a decrease in the minimum annular velocity from $31.412 \mathrm{ft} / \mathrm{min}$ to $1.828 \mathrm{ft} / \mathrm{min}$. Moreover, the flow behaviour index of the water-based bentonite drilling fluid decreased constantly up to a $7 \mathrm{wt} \%$ concentration of rice husk ash, while a $9 \mathrm{wt} \%$ concentration caused an increase in the flow behaviour index. However, the flow behaviour index decreased when the concentration of the rice husk ash was increased to 12.5 and $15 \mathrm{wt} \%$. The lowest flow behaviour index was obtained with drilling fluid samples blended with a $15 \mathrm{wt} \%$ concentration of rice husk ash. The addition of a $15 \mathrm{wt} \%$ concentration of rice husk ash to the drilling mud decreased the flow behaviour index from 0.419 to 0.087 .

Table 4. Cutting carrying index, minimum annulus velocity and flow behaviour index of water based bentonite mud with additive at different rice husk ash concentrations

\begin{tabular}{|l|c|c|c|}
\hline $\begin{array}{l}\text { Concentration of rice } \\
\text { husk ash (wt\%) }\end{array}$ & CCI & Vo & n \\
\hline 0 & 3.183 & 31.412 & 0.419 \\
\hline 2 & 5.516 & 18.126 & 0.347 \\
\hline 4 & 13.855 & 7.217 & 0.230 \\
\hline 7 & 17.103 & 5.846 & 0.207 \\
\hline 9 & 5.258 & 19.015 & 0.394 \\
\hline 12.5 & 22.101 & 4.5245 & 0.210 \\
\hline 15 & 54.700 & 1.828 & 0.087 \\
\hline
\end{tabular}

\subsection{Analysis of filtration}

In this section, the fluid loss volume, the mud cake thickness and the mud cake permeability of drilling fluid samples formulated in the absence and the presence of the different concentration of rice husk ash were analysed by comparing them to the base fluid.

Fluid loss can be defined as the amount of influx invaded to a porous and permeable formation due to high mud hydrostatic pressure and it is desired to achieve a fluid loss volume as low as possible, thereby preventing many severe and costly drilling problems resulting from high fluid loss, such as formation damage, stuck pipe, lost circulation, non-productive time, and so on. Fluid loss results are given in Figure 7. The results reveal that the addition of rice husk ash up to a $9 \mathrm{wt} \%$ concentration has a positive effect on the filtration of the water based bentonite mud as a result of a reduction in the filtrate volume. The drilling fluid system formulated with a $4 \mathrm{wt} \%$ concentration of rice husk ash experienced the lowest fluid loss volume decreasing by approximately $10 \%$. However, the formulation of drilling fluid systems with a 12.5 and $15 \mathrm{wt} \%$ concentration of rice husk ash adversely affected the fluid loss of the mud as a result of an increase in filtrate volume compared to the base drilling fluid. It should be highlighted that although mud systems formulated with a 12.5 and $15 \mathrm{wt} \%$ concentration of rice husk ash caused an increase in the fluid loss compared to the reference fluid, the values of fluid loss of the mud systems are within the accepted limits that are lower than $15 \mathrm{~mL}$ value determined by API standards. It should be noted that when this result is compared to the study conducted by (Saengdee and Terakulsatit, 2017) in which the use of sugar cane ash in water-based mud was investigated, it was observed that a $4 \%$ concentration of rice husk ash is relatively more effective in reducing fluid loss. In the authors' study, the lowest fluid loss was achieved at a $1 \%$ sugar-

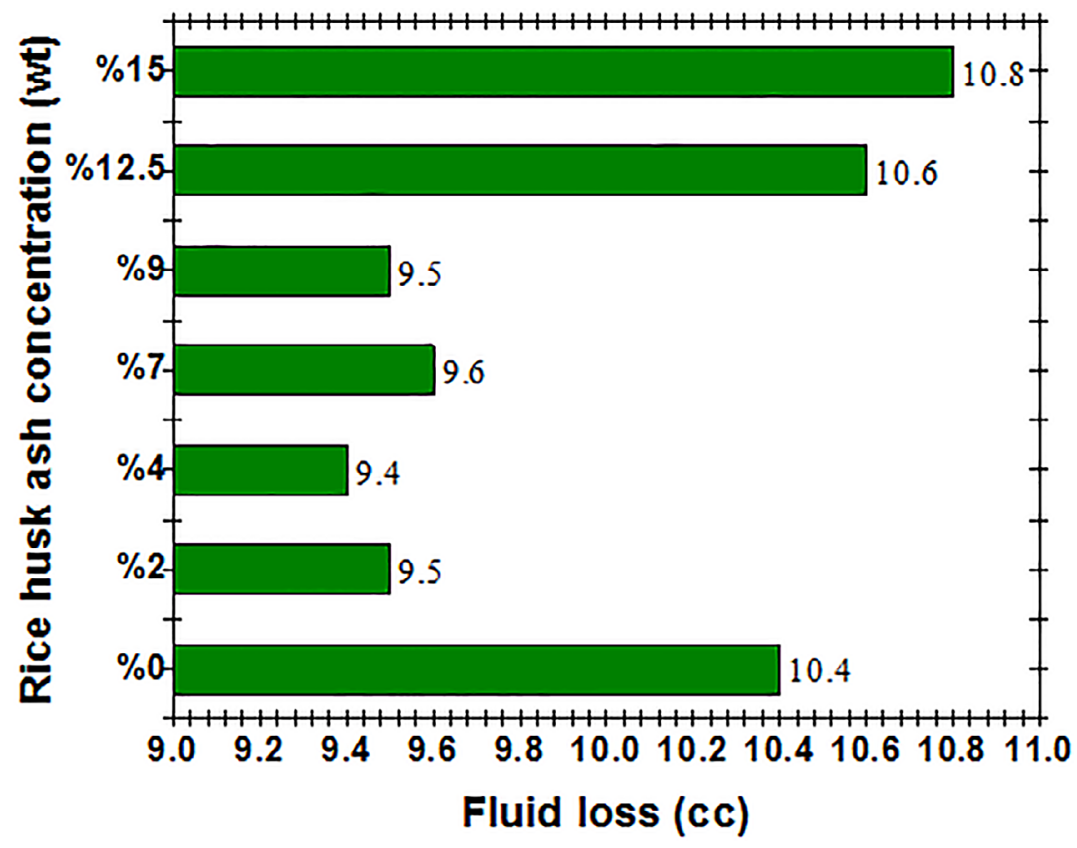

Figure 7: API fluid loss volume of water-based bentonite drilling fluid at different rice husk ash concentrations 


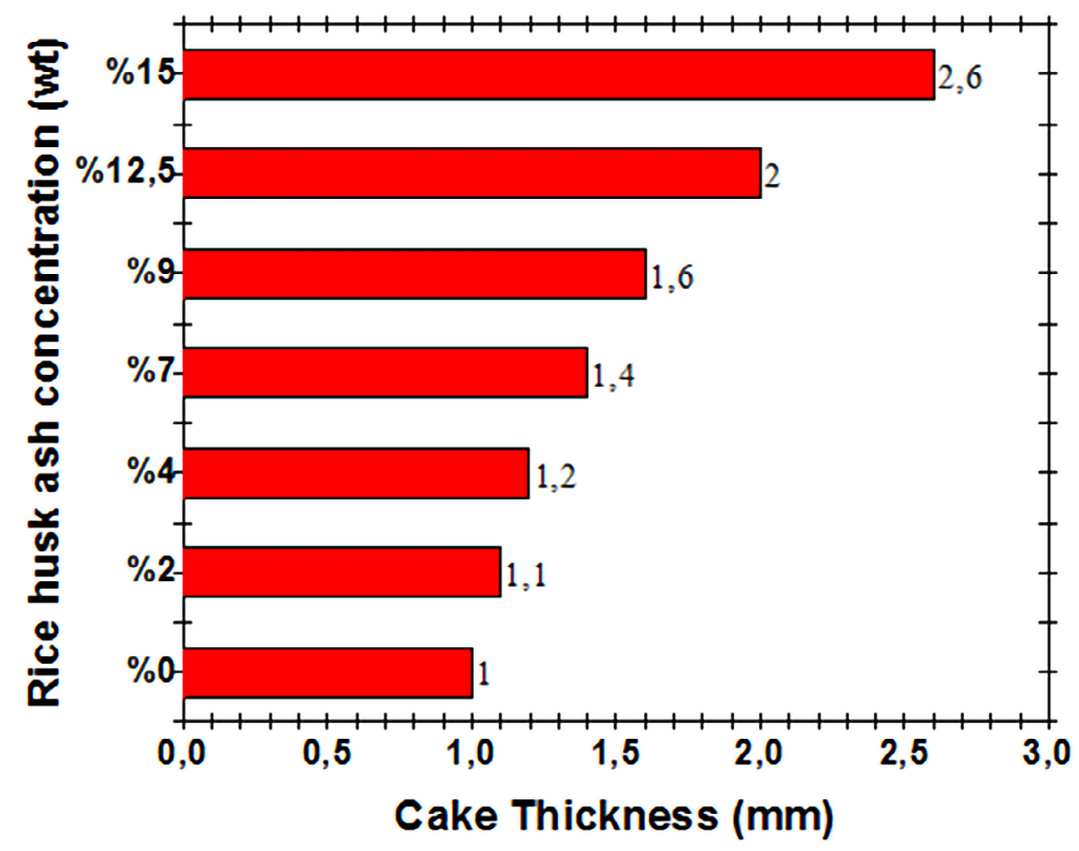

Figure 8: Filter cake thickness of water-based bentonite drilling fluid at different rice husk ash concentrations

cane ash concentration, with a fluid loss reduction of approximately $6 \%$.

The mud cake thickness of a drilling fluid is desired to be thin and impermeable to prevent lost circulation, stuck pipe and formation damage. Figure 8 shows the mud cake thickness results of the drilling fluid systems. Similar to the results of the research examining the use of rice husk in water-based drilling mud (Okon, 2014), it was observed that the mud cake thickness increased due to an increase in the amount of rice husk ash in the water-based bentonite drilling fluid. The results reveal that the addition of rice husk ash for all concentrations caused the formation of a thicker mud cake compared to the base fluid. However, Rabia (1985) expresses that the mud cake thickness of the drilling fluid should not exceed 3/32". In light of this expression, it should be noted that the mud cake thickness of the drilling fluid systems incorporated with rice husk ash for all concentrations, except a $15 \mathrm{wt} \%$ concentration of rice husk ash, are within the accepted limits, lower than $3 / 32$ " and ranging from $1.1 \mathrm{~mm}$ to 2 $\mathrm{mm}$. Compared to a study in the literature, it was observed that thinner mud cakes were obtained in this study. For instance, (Agwu et al., 2019) in their study, in which both sawdust and rice husk were used in water-based drilling mud, mud cakes of non-acceptable thickness were obtained. Mud cakes between $2.8 \mathrm{~mm}$ and $3.8 \mathrm{~mm}$ were obtained with rice husk, while mud cake thicknesses between $2.6 \mathrm{~mm}$ and $3.3 \mathrm{~mm}$ were obtained with sawdust.

Mud cake permeability indicates the ability of the formed mud cake to prevent or allow the drilling fluid filtrate to enter a formation. Table 5 demonstrates the results of the variation of mud cake permeability with the use of rice husk ash at different concentrations. The results indicate that drilling fluid systems formulated with rice husk ash for all concentrations, except for 2 $\mathrm{wt} \%$, showed a negative effect on the mud cake permeability of the water-based bentonite drilling fluid. It was observed that the mud cake permeability ratio was greater than a value of 1 and steadily increased as the concentration of rice husk ash increased due to the increased mud cake thickness. However, the drilling fluid system formulated with a $2 \mathrm{wt} \%$ concentration rice husk ash yielded a reduction of the mud cake permeability ratio compared to the base fluid.

Table 5. The ratio of mud cake permeability of drilling fluids with different rice husk ash concentrations in comparison to the base fluid

\begin{tabular}{|l|c|}
\hline Concentration of rice husk ash (wt\%) & $\mathbf{k}_{\mathbf{r h a}} / \mathbf{k}_{\mathbf{b}}$ \\
\hline 0 & 1 \\
\hline 2 & 0.913 \\
\hline 4 & 1.187 \\
\hline 7 & 1.191 \\
\hline 9 & 1.130 \\
\hline 12.5 & 1.394 \\
\hline 15 & 1.324 \\
\hline
\end{tabular}

Density is one of the main parameters of drilling fluid and it controls the formation pressure to prevent blowout. Figure 9 shows the density results of the drilling fluid systems designed in the absence and the presence of different concentration of rice husk ash. The results demonstrate that the density of the water-based bentonite mud increases steadily with the increasing concentration of rice husk ash and the highest density was obtained when a 


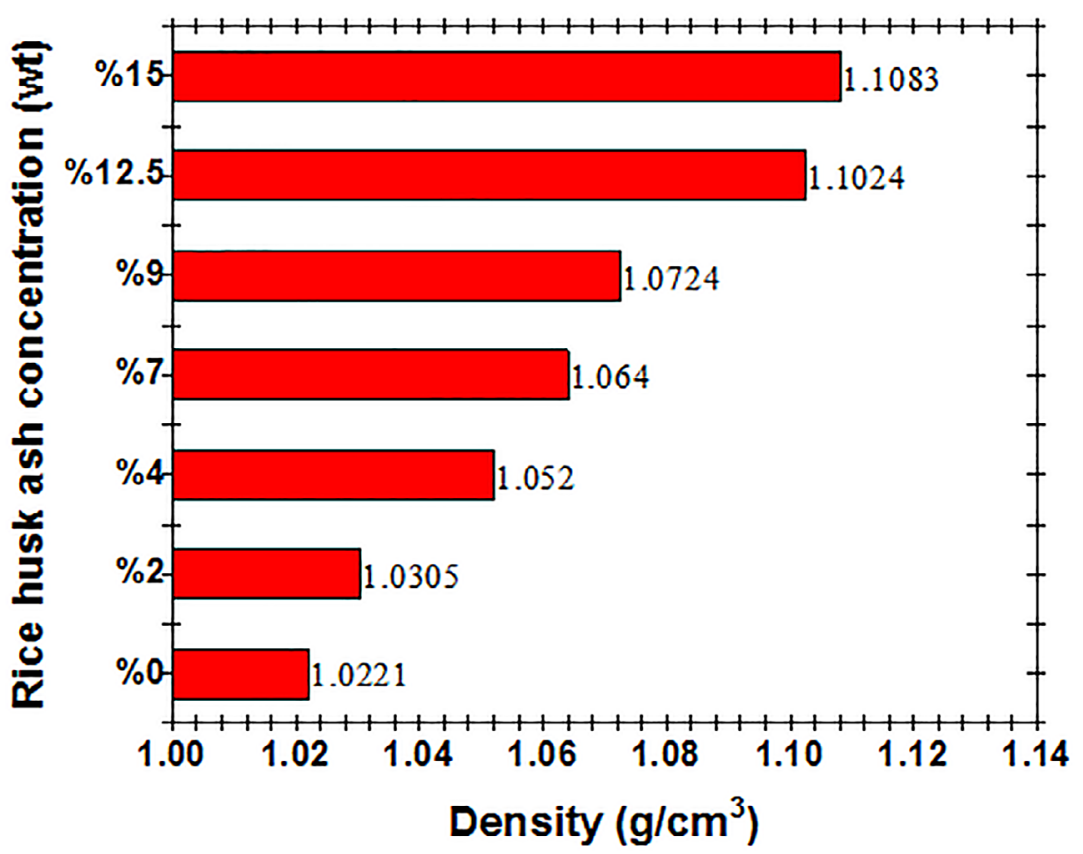

Figure 9: Density of water-based bentonite drilling fluid at different rice husk ash concentrations

$15 \mathrm{wt} \%$ concentration of rice husk ask was introduced to the base fluid. The increased density can be attributed to an increased solid mass in the mixture with the addition of an increasing amount of rice husk ash.

\section{Conclusions}

In this study, the usage of rice husk ash with the introduction of different concentrations in water-based bentonite drilling fluid were experimentally investigated at ambient temperature. Moreover, the cutting carrying capacity, the minimum annular velocity required for effective hole cleaning and the flow behaviour index of the muds were computed and compared with a drilling fluid not containing rice husk ash. The results showed that the rheology of the drilling fluid substantially improved with the addition of increasing concentrations of rice husk ash into the mud, particularly at high concentrations $(12.5$ and $15 \mathrm{wt} \%)$. The optimum results with respect to rheology were obtained with the drilling fluid system incorporated with a $15 \mathrm{wt} \%$ concentration of rice husk ash. Water-based bentonite drilling fluid with the addition of a $15 \mathrm{wt} \%$ concentration of rice husk ash could perform denser, higher cutting carrying capacity, apparent viscosity, yield point and lower fluid behaviour index, minimum annular velocity, plastic viscosity and thixotropy significantly compared to the drilling fluid without rice husk ash. On the other hand, it was observed that while a low concentration of rice husk ash up to 9 wt $\%$ improved the filtrate volume, the addition of 12.5 and $15 \mathrm{wt} \%$ rice husk ash into the mud increased the fluid loss. Moreover, the addition of high concentrations of rice husk ash caused an increase in the filter cake and mud cake permeability, except for the lowest concentra- tion $(2 \mathrm{wt} \%)$. However, the increased fluid loss volume, filter cake and mud cake permeability are within the acceptable limits. The novel findings from this study indicate that the proper implementation of rice husk ash in water-based bentonite mud would be a welcome improvement in the drilling industry and could be used as a guide for future studies.

\section{Acknowledgement}

This study was produced from the first author's $\mathrm{PhD}$ thesis.

\section{References}

Adnan, Z. S., Ariffin, N. F., Mohsin, S. M. S. and Lim, N. H. A. S. (2021): Performance of rice husk ash as a material for partial cement replacement in concrete. Materials Today: Proceedings, in press. https://doi.org/10.1016/j.matpr.2021.02.400.

Agwu, O. E., Akpabio, J. U. and Archibong, G. W. (2019): Rice husk and saw dust as filter loss control agents for water-based muds. Heliyon, 5, 7, 185-198. https://doi. org/10.1016/j.heliyon.2019.e02059

Akeke, G. A., Ephraim, M. E., Akobo, I. Z. S. and Ukpata, J. O. (2013): Structural properties of rice husk ash concrete. International Journal of Engineering, 3, 3, 57-62. http:// dx.doi.org/10.1016/j.cemconcomp.2014.09.008.

Al-Hameedi, A. T. T., Alkinani, H. H., Dunn-Norman, S., AlAlwani, M. A., Feliz, J. D., Alshammari, A. F. and Al-Bazzaz, W. H. (2019c): Laboratory Study of Environmentally Friendly Drilling Fluid Additives to be used a Thinner in Water-Based Muds. In Abu Dhabi International Petroleum Exhibition \& Conference. Society of Petroleum Engineers. 
Al-Hameedi, A. T. T., Alkinani, H. H., Dunn-Norman, S., AlAlwani, M. A., Alshammari, A. F., Albazzaz, H. W. and Al-Bazzaz, W. H. (2019): Proposing a new eco-friendly drilling fluid additive to enhance the filtration properties of water-based drilling fluid systems. In SPE Gas \& Oil Technology Showcase and Conference. Society of Petroleum Engineers.

Al-Hameedi, A. T. T., Alkinani, H. H., Dunn-Norman, S., Alashwak, N. A., Alshammari, A. F., Alkhamis, M. M. and Ashammarey, A. (2019b): Evaluation of environmentally friendly drilling fluid additives in water-based drilling mud. In SPE Europec featured at 81st EAGE Conference and Exhibition. Society of Petroleum Engineers.

Al-Hameedi, A. T. T., Alkinani, H. H., Dunn-Norman, S., Alashwak, N. A., Alshammari, A. F., Alkhamis, M. M. and Alsaba, M. T. (2019a): Environmental friendly drilling fluid additives: can food waste products be used as thinners and fluid loss control agents for drilling fluid. In SPE Symposium: Asia Pacific Health, Safety, Security, Environment and Social Responsibility. Society of Petroleum Engineers.

Al-Hameedi, A. T. T., Alkinani, H. H., Dunn-Norman, S., Salem, E., Knickerbocker, M. D., Alashwak, N. F. and AlBazzaz, W. H. (2020): Laboratory Study of Environmentally Friendly Drilling Fluid Additives Banana Peel Powder for Modifying the Drilling Fluid Characteristics in Water-Based Muds. In International Petroleum Technology Conference. OnePetro.

Al-Saba, M. T., Amadi, K. W., Al-Hadramy, K. O., Al Dushaishi, M. F., Al-Hameedi, A. and Alkinani, H. (2018): Experimental investigation of bio-degradable environmental friendly drilling fluid additives generated from waste. In SPE International Conference and Exhibition on Health, Safety, Security, Environment, and Social Responsibility. Society of Petroleum Engineers.

Amanullah, M. (2007): Screening and Evaluation of Some Environment-Friendly Mud Additives to Use in WaterBased Drilling Muds. SPE E\&P Environmental and safety conference. Galveston, Texas, USA.

Azar, J. J. and Samuel, G. R. (2007): Drilling engineering. PennWell books. Oklahoma, USA, $471 \mathrm{p}$.

Biwott, T. C., Kiprop, A. K., Akaranta, O. and Oriji, B. (2019): Improving the rheological properties of water based mud with moringa oleifera leaves. Chemical Science International Journal, 28, 4, 1-9.

Bourgoyne, A. T., Millheim, K. K., Chenevert, M. E. and Young, F. S., (1991): Applied drilling engineering. SPE Textbook Series, Dallas, TX, 2.

Buggenhout, J., Brijs, K., Celus, I. and Delcour, J. A. (2013): The breakage susceptibility of raw and parboiled rice: A review. Journal of Food Engineering, 117, 3, 304-315.

Caenn, R., Darley, H. C. Darley, and Gray, G. R. Gray. (2011): Composition and properties of drilling and completion fluids. 6th ed. USA. Gulf professional publishing.

Chandrasekhar, S. and Pramada, P. N. (2006): Rice husk ash as an adsorbent for methylene blue effect of ashing temperature. Adsorption, 12, 1, 27-43. https://doi.org/10.1007/ s10450-006-0136-1
Culver, G. (1998): Drilling and well construction, Chapter 6: Geothermal Direct Use Engineering and Design Guidebook, Geo-Heat Center, Klamath Falls, OR.

Dandekar, A. Y. (2013): Petroleum reservoir rock and fluid properties. CRC press.

Fernandes, I. J., Calheiro, D., Kieling, A. G., Moraes, C. A., Rocha, T. L., Brehm, F. A. and Modolo, R. C. (2016): Characterization of rice husk ash produced using different biomass combustion techniques for energy. Fuel, 165, 351-359. 10.1016/j.fuel.2015.10.086

Kieling AG. (2009): Influência da segregação no desempenho de cinzas de casca dearroz como pozolanas e material adsorvente. MSc dissertation, Universidadedo Vale do Rio dos Sinos, UNISINOS, São Leopoldo, RS, Brazi (in Portuguese- there is English abstract).

Kök, M. V. and Bal, B. (2019): Effects of silica nanoparticles on the performance of water-based drilling fluids. Journal of Petroleum Science and Engineering, 180, 605-614. https://doi.org/10.1016/j.petrol.2019.05.069

Malhotra, V. M. (1993): Fly ash, slag, silica fume and rice husk ash in concrete: A review. Concrete International, 15, 4, 23-28.

Okon, A. N., Udoh, F. D. and Bassey, P. G. (2014): Evaluation of Rice Husk as Fluid Loss Control Additive in WaterBased Drilling Mud. SPE Nigeria Annual International Conference and Exhibition. Lagos, Nigeria.

Prasara-A, J. and Gheewala, S. H. (2017): Sustainable utilization of rice husk ash from power plants: A review. Journal of cleaner production, 167, 1020-1028.

Rabia, H. (1985): Well Engineering and Construction, Graham and Trotman, Oxford, UK.

Rabia, H. (2002): Well Engineering \& Construction. London: Entrac Consulting Limited.

Recommended Practice, (1988): Standard procedure for field testing drilling fluid, 12th ed. Recommended Practice, vol.13. API, Washington, USA. (B(RP13B)), pages. 7-9.

Rodriguez de Sensale, R. (2006). Strength development of concrete with rice-husk ash. Cement and concrete composites, 28, 2, 158-160. https://doi.org/10.1016/j.cemconcomp.2005.09.005

Saengdee, A. and Terakulsatit, B. (2017): Utilization of Sugarcane Bagasse Ash as Filtration Loss Control Agent in Water Based Drilling Muds. UBU Engineering Journal, 10, 1, $37-48$.

Skalle, P., (2011): Drilling Fluid Engineering, Ventus Publishing ApS, $132 \mathrm{p}$.

Thomas, B. S. (2018): Green concrete partially comprised of rice husk ash as a supplementary cementitious material-A comprehensive review. Renewable and Sustainable Energy Reviews, 82,3, 3913-3923. https://doi.org/10.1016/j. rser.2017.10.081

Zhang, L., Wu, X., Sun, Y., Cai, J. and Lyu, S. (2020): Experimental study of the pomelo peel powder as novel shale inhibitor in water-based drilling fluids. Energy Exploration \& Exploitation, 38, 2, 569-588. https://doi.org/10.1177/ 0144598719882147 


\section{SAŽETAK}

\section{Novi ekološki prihvatljivi i jeftiniji aditivi za isplake na bazi vode}

Istražene su mogućnosti upotrebe pepela rižine ljuske kao aditiva za pripremu ekološki prihvatljivijih i jeftinijih isplaka. Pepeo rižine ljuske dodan je u bentonitnu isplaku u različitim koncentracijama u rasponu od 2 do $15 \%$ maseno. Reološka i filtracijska svojstva pripremljenih isplaka mjerena su upotrebom viskozimetra i standardne API filtar preše. Naknadno, kako bi se bolje procijenila svojstva ispitivanih isplaka određen je indeks iznošenja krhotina, minimalna brzina protjecanja isplake u prstenastome prostoru potrebna za efikasno čišćenje dna bušotine, indeks toka te propusnost isplačnoga obloga. Dobiveni rezultati upućuju na poboljšanje reoloških i ostalih svojstava ispitivanih isplaka u ovisnosti o korištenoj koncentraciji pepela rižine ljuske. Kod isplake u koju je dodano 15 \% maseno pepela rižine ljuske uočeno je povećanje prividne viskoznosti za $60 \%$ i naprezanja pri pokretanju za $183 \%$, dok su tiksotropna svojstva i plastična viskoznost smanjeni za $29 \%$ odnosno $63 \%$. S druge strane, kod isplaka koje su pripremljene s $4 \%$ maseno pepela rižinih ljuski izmjereno je smanjenje filtracije za $10 \%$. Štoviše, rezultati upućuju na poboljšanje indeksa iznošenja krhotina, smanjenje minimalne vrijednosti brzine protoka u prstenastome prostoru za efikasno čišćenje dna bušotine i vrijednosti indeksa toka kod upotrebe pepela rižinih ljuski u isplaci. Ovo istraživanje jasno pokazuje da je pravilnom primjenom pepela rižinih ljuski kao aditiva u bentonitnoj isplaci moguće smanjiti utjecaj na okoliš i troškove bušenja.

\section{Ključne riječi:}

isplake, pepeo rižine ljuske, ekološki prihvatljivo, sposobnost iznošenja krhotine, reologija, filtracija

\section{Author's contribution}

Emine Yalman (PhD student, Petroleum Engineer) and Hani Al Khalaf (PhD student, Petroleum Engineer) performed the laboratory tests and the presentation of the results. Tolga Depci (Prof. Dr., Mining Engineer) and Gabriella Federer-Kovacs (Assoc. Prof. Dr., Petroleum Engineer) provided analyses of the results. 